\title{
Ambigüedad y humorismo
}

\author{
Ambiguity and Humour
}

\author{
Saad MOHAMED SAAD \\ Universidad Pablo de Olavide de Sevilla \\ smohsaa@upo.es
}

Recibido: enero 2012

Aceptado: febrero 2012

\begin{abstract}
RESUMEN
Contra lo que pudiera creerse en un primer momento, la ambigüedad del lenguaje tiene numerosos efectos positivos para los componentes esenciales de los actos de habla: los interlocutores, el mensaje y el código. En este trabajo nos proponemos estudiar uno de esos aspectos positivos relacionados con la ambigüedad semántica: el humor, que en muchas ocasiones se origina en la dilogía de ciertas unidades lingüísticas que aparecen en el discurso. En nuestro estudio, distinguimos entre tres tipos básicos de opacidad semántica: ambigüedad, vaguedad e indeterminación. Para crear la comicidad en el texto, cada una de esas tres categorías echa mano de un conjunto de mecanismos distinto. El análisis aplicado en esta ocasión es de carácter pragmático.
\end{abstract}

Palabras clave: Ambigüedad, humor.

\begin{abstract}
Ambiguity has many positive effects on the three main elements of speech acts: speakers, message and code. In this paper, we will analyse one of the positive aspects related to semantic ambiguity: humour, which is often based on the ambivalence of certain units of speech. We will also establish three basic types of semantic opacity: ambiguity, fuzziness and generality. Our pragmatic approach will show how several mechanisms account for the way each one of these categories creates humour.
\end{abstract}

Keywords: Ambiguity, humour.

SUMARIO: 1. Ambigüedad, vaguedad e indeterminación, 2. Ambigüedad y humorismo, 2.1. El uso de la expresión insolente o comprometedora, 2.2. La violación de la congruencia del texto, 2.3. La violación del principio de convencionalidad semántica, 3. Indeterminación semántica y humorismo, 3.1. Indeterminación referencial, 3.2. Indeterminación elocutiva, 3.3. Indeterminación codificadora, 3.3.A. La elipsis de secuencias fácilmente recuperables, 3.3.B. Pistas de la interpretación figurada, 4. Vaguedad y humorismo, 5. Conclusiones, 5.1. Ambigüedad y humorismo, 5.2. Indeterminación y humorismo, 5.3. Vaguedad y humorismo. 
En su segundo apartado, la tercera de las máximas conversacionales que, según el filósofo británico P. Grice, rigen el uso del lenguaje como herramienta de comunicación verbal, incita a todo emisor a evitar la ambigüedad en su interacción lingüística. ${ }^{1} \mathrm{Y}$ aunque de hecho los hablantes procuran, en circunstancias normales y en la medida de lo posible, ser respetuosos siempre con dicho precepto en sus actuaciones lingüísticas, no es difícil darse cuenta de que "la ambigüedad es, sin lugar a dudas, uno de los universales más patentes del lenguaje natural". ${ }^{2}$ En realidad, los usuarios del lenguaje se ven sometidos en este sentido a dos fuerzas antagónicas: la necesaria nitidez con la que han de revestir los mensajes que transmiten -en aras de una comunicación eficaz y fluida-, y el deseo de no convertir sus interacciones lingüísticas en meros actos monótonos carentes de todo atisbo de creatividad. De ahí que algunos investigadores afirmen que:

"The Gricean sub-maxim of perspicuity, of his maxim of manner, should therefore be complemented by the maxim of 'conspicuity', the first having a homogenising effect on language and communication, the latter a heterogenizing effect. The fact that it is more costly [...] to process 'conspicuous' and interesting utterances than perspicuous ones, is the price we pay to keep communication and language going".

Varias son las razones que invitan a los hablantes a infringir el precepto griceano de "claridad" en su uso diario del lenguaje. Dichas razones no sólo se agrupan en torno a los interlocutores implicados en el acto de habla, sino que también pueden estar relacionadas tanto con el mensaje como con el propio código. En relación con aquéllos, es fácil observar que "in everyday speech, people who are able to perceive [...] ambiguities, or to provoke them, are considered clever or witty". ${ }^{4}$ Así, los hablantes recurren con frecuencia a la ambigüedad para demostrar su habilidad en el uso del lenguaje y/o captar un mayor grado de atención por parte del receptor para el mensaje que están transmitiendo. Con la ambivalencia, los interlocutores suelen experimentar una gran satisfacción, se crea un cierto grado de complicidad entre las partes implicadas en el diálogo y la interacción lingüística se vuelve más amena. En otras ocasiones, los mensajes poco transparentes son también utilizados como un mecanismo eficiente para rebajar la tensión entre los participantes en el diálogo. La ambigüedad del lenguaje desempeña, en definitiva, un gran papel como elemento de cohesión entre los interlocutores.

En lo que al mensaje se refiere, podemos afirmar que la ambivalencia se vincula tanto con la forma como con el contenido que se quiere transmitir. Para demostrar su importancia para la primera, basta recordar los valores estéticos que suelen correr parejos con la anfibología en cualquier texto literario, y en especial en los de carácter

\footnotetext{
${ }^{1}$ Cfr. Grice, P.: "Logic and conversation”, en P. Cole y J. Morgan (eds.): Syntax and Semantics, 3: Speech Acts, Academic Press, New York, 1975, 41-58.

${ }^{2}$ Michelena, L.: "De la ambigüedad sintáctica”, Revista Española de Lingüistica, II, fasc. 2 (1972), 237-247.

${ }^{3}$ Nerlich, B. y Clarke, D.: "Ambiguities we live by: Towards a pragmatics of polysemy", Journal of Pragmatics, 33 (2001), 1-20.

${ }^{4}$ Sánchez Roura, M. T.: "Sintactic ambiguity as a device in British humour", Revista Alicantina de Estudios Ingleses, 8 (1995), 209-228.
} 
poético. La riqueza lingüística de tales textos se atribuye, en gran medida, a la diversidad de sentidos que encierran, debido a la dilogía de muchos de sus elementos. Como bien podemos observar, en ocasiones el uso cotidiano del lenguaje se muestra también permeable a ciertos valores estéticos, que en principio son propios de la poesía, ofreciéndonos, de esta forma, frecuentes ejemplos de bisemia, símil, metáfora, etc. Así, el efecto de la ambigüedad es fácilmente extensible a los aspectos estéticos y formales del habla diaria. En relación con el contenido, acertadamente se ha señalado que el recurso a mensajes poco transparentes se debe al hecho de que:

"Most of the time we answer vaguely, because we either don't know the exact answer, or because we realize that in between the endpoints of 'affirmative' and 'negative', there is a multitude of possible answers. But perhaps even more importantly, we don't have to answer every question that is popped at us, and certainly there is no law that obliges us to tell the truth to people". ${ }^{5}$

Para el código, la ambigüedad se presenta como uno de los recursos más frecuentes de innovación lingüística, puesto que, al igual que en el caso de la metáfora, en muchas ocasiones su uso suele suponer el primer paso hacia la creación y asignación de nuevas acepciones a palabras que en principio no las comportan. En este sentido, y para poner un ejemplo, conviene recordar que los eufemismos son formas ambiguas de expresar ciertos significados comprometidos mediante el uso de palabras que originalmente no los expresan. Con el paso del tiempo, muchas de esas palabras pasan a tener como propios los nuevos valores que le fueron asignados. Así se explican, por ejemplo, las acepciones que actualmente se asignan en español a vocablos como servicios, tercera edad, dar a luz, etc. No obstante, los beneficios de la laxitud semántica tienen mayor alcance que la simple innovación léxica, puesto que sus verdaderas raíces se encuentran en el propio principio de economía del lenguaje; el carácter borroso y poco preciso que muestran las unidades lingüísticas es una garantía para la necesaria flexibilidad y el fácil manejo que precisa el buen funcionamiento del código.

Así pues y contra lo que pudiera creerse en un primer momento, la ambigüedad del lenguaje tiene numerosos efectos positivos para los componentes esenciales de los actos de habla: los interlocutores, el mensaje y el código. En este trabajo nos proponemos estudiar uno de esos aspectos positivos relacionados con la ambigüedad semántica: el humor, que en muchas ocasiones se origina en la dilogía de ciertas unidades lingüísticas que aparecen en el discurso. Para ello, empezaremos por analizar los distintos fenómenos que se caracterizan por su opacidad semántica, para pasar luego a examinar el funcionamiento de dichas unidades dentro del discurso humorístico. En este estudio, nuestro corpus estará formado por cinco novelas de Naguib Mahfuz y un conjunto de anécdotas de Ŷuhāa. ${ }^{6}$

${ }^{5}$ Mey, J. L.: "Context and (dis)ambiguity: a pragmatic view", Journal of Pragmatics, 35 (2003), 331-347.

${ }^{6}$ Las novelas de Naguib Mahfuz que han servido de base para nuestro estudio son: Jān al-Jalīlī, en Mahfuz, Naguib: al-Mu'allafāt al-Kāmila, Maktabat Lubnān Nāširūn, Beirut, 1990, vol. I, pp. 522638; Bayn al-Qașrayn, Qașr al-Shawq, al-Sukkariyya, en al-Mu'allafāt al-Kāmila, 1991, vol. II, pp. 325-970 y Zuqāq al-Madaq, Dār al-Qalam, Beirut, 1972. Las anécdotas de Ŷuhā son las que aparecen recopiladas en Raŷb al-Naŷŷār, Muḥammad: ŶYhạ -l- 'Arabī, al-Maŷlis al-Wațanī li-l-Ṭaqāfa wa -l- 


\section{AMBIGÜEDAD, VAGUEDAD E INDETERMINACIÓN}

La opacidad del lenguaje se manifiesta bajo tres formas distintas, que conviene no confundir: la ambigüedad, la vaguedad y la indeterminación. Se trata de tres fenómenos que se originan en tres áreas diferentes de la dimensión semiótica del lenguaje. Por su parte, el receptor suele resolver las dificultades surgidas en diferentes momentos del proceso de interpretación. Los siguientes decursos nos pueden servir de ejemplo para las tres categorías señaladas:

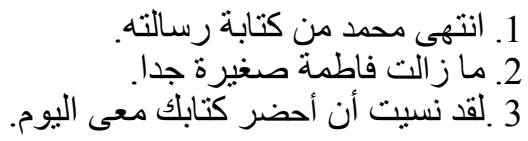

La ambigüedad del primer enunciado se basa en el hecho de que la palabra (رسالة) se puede interpretar de, al menos, dos formas: como tesis o como carta. El problema de la interpretación radica en este caso en la superposición de significados correspondientes a dos signos distintos. Este hecho nos permite afirmar con S. Gutiérrez Ordóñez que "a toda ambigüedad subyace una homonimia". En cambio, la opacidad semántica que se puede percibir en la segunda oración se debe a que el segmento (ماز الت صغيرة جدا) se puede entender de distintas maneras. Dependiendo del caso concreto del que se hable, se le puede atribuir un sentido u otro. Así pues, si estamos hablando de una adolescente que quiere viajar sola al extranjero o de una persona que se quiere independizar, el valor real que se les puede atribuir a estas palabras puede ser cualquier edad que se ubique por debajo de, por poner una cifra, los dieciocho o veinte años. Este valor se moverá -mucho o poco- hacia arriba o hacia abajo si se está hablando de matricular a una niña en los estudios secundarios, la jubilación de una persona o la edad a la que suelen morir los ancianos. Aquí, el problema no radica en la multiplicidad de significados que pueda comportar el segmento señalado, sino en los valores reales que pueden ser designados por las palabras que lo integran. Como habremos podido observar, el ámbito real que pueden abarcar estas palabras puede oscilar sorprendentemente entre, digamos, los cinco y los más de sesenta y cinco años. Lo que aquí denominamos vaguedad se diferencia de los otros dos fenómenos por el hecho de que "it refers to an indeterminate referential boundary. [...] It is not resolvable, even with resort to context". ${ }^{8}$ Es un hecho que se ubica, por lo tanto, en la designación y no en la significación, como es en el caso de la ambigüedad o la indeterminación. ${ }^{9}$ A su vez, el segmento (كتابك), que aparece en la tercera oración, puede referir a un conjunto de valores, tales como "el libro que has escrito", "has comprado", "has pedido", etc. La opacidad semántica de este

Funūn wa -1- Ādāb, Kuwait, 1978. A todas estas obras aludiremos, de ahora en adelante, con siglas constituidas por las letras iniciales de las palabras que forman sus títulos.

${ }^{7}$ Gutiérrez Ordóñez, S.: Lingüística y semántica (aproximación funcional), Servicio de Publicaciones de la Universidad de Oviedo, Oviedo, 1981, 241.

${ }^{8}$ Zhang, Q.: "Fuzziness - vagueness - generality - ambiguity", Journal of Pragmatics, 29 (1998), 13-31.

${ }^{9}$ Cfr. Gutiérrez Ordóñez, S.: De pragmática y semántica, Arco/Libros, Madrid, 2002, 349. 
sintagma sólo puede ser despejada por la información enciclopédica compartida por el emisor y el receptor en una situación de discurso concreta.

La delimitación entre la ambigüedad, por un lado, y la vaguedad e indeterminación semántica, por el otro, se basa en la existencia o no en el enunciado de un caso evidente de homonimia. Como ya hemos comentado anteriormente, para que haya ambigüedad es una condición imprescindible que en el enunciado aparezca un segmento con más de un significado, sin relación aparente entre sí. A su vez, la vaguedad se distingue de la indeterminación por el hecho de que la primera ha de basarse siempre en un elemento que posee fronteras borrosas con otros términos del mismo idioma. En general, los lexemas que se caracterizan por la vaguedad semántica son unidades lingüísticas que expresan un grado determinado dentro de una escala dada o aluden, en su defecto, a una clase concreta de elementos opuestos a otros, que pueden ser designados por otra(s) palabra(s). Así, en el caso del adverbio (جدا), podemos observar fácilmente que dicha palabra ocupa un lugar concreto en una escala formada por otros elementos como (جسيان),

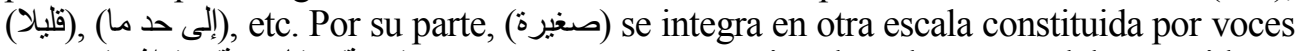
como (ناضجة), (نسنة), etc. Lo más característico de todas esas palabras reside en el carácter borroso de las fronteras que las delimitan. Por su parte, los términos que no expresen esta idea de escala, tienen que referirse, inevitablemente, a una clase de elementos opuesta, por lo menos, a otra clase de la misma categoría. Como ejemplo de este último supuesto, podemos pensar en una palabra como (الطير). Bajo este término se agrupan animales como (النسر), (الحدامة), (الحدة), etc. Frente a esta categoría se erige otra integrada por animales como (الأسد)(القرد)(القط)( القد), etc., todos ellos agrupables bajo el término de (الثنييات). Al igual que en el caso de los lexemas con significado escalar, aquí también la frontera se presenta borrosa, puesto que un término como (خفاش) nos puede plantear dudas a la hora de querer incluirlo bajo la categoría de ave o mamífero. ${ }^{10}$ Tanto los elementos de semántica escalar como los términos categorizadores precisan de una perspectiva concreta que todo emisor ha de adoptar para referirse a los hechos de la realidad externa mediante el uso de un lexema u otro. Así pues, lo que un hablante concreto en una situación dada puede calificar como bueno, otro emisor con otra perspectiva lo puede tachar de malo. Por otra parte, el contexto y/o la situación del discurso pueden orientar la perspectiva del receptor en un sentido $\mathrm{u}$ otro, tal como podemos observar si al segundo decurso le añadimos un segmento que en árabe comporte un sentido similar a "para viajar sola a París" o si el enunciado es proferido en una situación en la que se habla de matricular a los hijos en una escuela de estudios secundarios. Sin embargo, con este tipo de opacidad semántica habrá siempre puntos conflictivos ante los que surgirán dudas a la hora de elegir un término u otro contiguo para designar ciertos hechos de la realidad externa.

La situación es totalmente distinta en el caso de la indeterminación semántica. Bien es verdad que ésta también depende de la situación del discurso, de tal forma que lo que a un receptor le puede parecer semánticamente indeterminado, comportará una cantidad suficiente de información para otra persona en una situación diferente.

${ }^{10}$ Cfr. Lakoff, G.: "Hedges: a study in meaning criteria and the logic of fuzzy concepts", Journal of Philosophical Logic, 2 (1973), 458-508. 
Sin embargo, los hechos no precisan aquí de ninguna perspectiva, sino que tienen que ver más bien con la información enciclopédica a la que puede acceder el receptor en relación con el motivo del diálogo. Así pues, si a nosotros nos parece semánticamente indeterminado el valor que transmite el posesivo "ك" en el ejemplo anteriormente aducido, nuestras dudas quedarán totalmente despejadas si nos informan de que este enunciado lo ha proferido el responsable de una editorial en una conversación mantenida con un escritor al que acaban de publicar un nuevo libro. En otros casos, la indeterminación de un lexema puede quedar despejada por otros elementos que aparecen posteriormente en el contexto, proporcionando la información que precisa el receptor. Las fronteras que delimitan los términos implicados en la indeterminación frente a otros de su misma categoría no se presentan tan borrosas como en el caso de la vaguedad, por lo cual nunca surgen hechos conflictivos para la designación. De esta forma, si en una oración como:

$$
\text { - مند حاصلة على درجة الليسانس. }
$$

El significado que comporta la palabra (الليسانس) nos puede parecer indeterminado, añadiendo un segmento como (في اللغة الألمانية و آدابها من جامعة القاهرة), su indeterminación quedará totalmente resuelta. Por el contrario, en ningún caso surgirán dudas acerca de la designación de dicho término, puesto que, o se es licenciado o no. Bajo circunstancias normales, no habrá nunca personas que se consideren licenciadas desde la perspectiva de unos y no licenciadas desde la perspectiva de otros.

Pese a todo lo que venimos estableciendo, conviene recordar que la separación entre ambigüedad, vaguedad e indeterminación no tiene por qué ser siempre tajante, puesto que un segmento puede llegar a ser ambiguo, vago e indeterminado a la vez. Para poner un ejemplo, podemos reparar en el contenido de un lexema como (حن). Semánticamente, el contenido de esta palabra en sí misma es ambiguo, vago e indeterminado a la vez. Su ambigüedad se debe a la homonimia que encierra, puesto que como adjetivo transmite un valor distinto al que comporta si se usa como interjección:

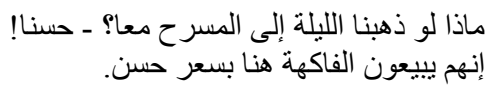

Por otro lado, el adjetivo (حسن) es un signo que posee un contenido escalar, por lo cual su aplicación a los hechos de la realidad externa estará siempre sujeta, en una medida u otra, al criterio subjetivo de los hablantes. Desde este punto de vista, está claro que se trata de un lexema con un significado vago. No obstante, la posibilidad de precisar la acepción que transmite mediante la complementación sintáctica es un síntoma más que suficiente de su indeterminación:

$$
\text { فاطمة حسنة النية و لكنها سيئة الحظ. }
$$

Todo ello nos hace pensar que el problema de la opacidad semántica siempre surge y es resuelto en el contexto y/o la situación del discurso. Es una cuestión que no se limita, pues, a lo puramente semántico, sino que tiene una dimensión evidentemente pragmática. 
Tal como hemos establecido al principio de esta sección, los tres fenómenos de opacidad semántica que venimos analizando se producen en tres áreas diferentes del plano semiótico del lenguaje: la puesta en relación de significantes y significados, la segmentación de las áreas de dominio que pueden cubrir los signos a la hora de ser aplicados a los hechos de la realidad externa y la cantidad de información que pueden transmitir en cada caso, respectivamente. No obstante, la diferencia entre ambigüedad, vaguedad e indeterminación no se limita a la semiosis, sino que también se extiende a la interpretación de los mensajes, puesto que los problemas de sentido que se originan en torno a estos tres fenómenos se resuelven en distintas fases de este proceso. Si tomamos como ejemplo el modelo de interpretación de la teoría de Relevancia, pronto nos daremos cuenta de ello.

Para esta teoría, durante el proceso de interpretación de los enunciados la labor del oyente se centra en la identificación de dos aspectos básicos del contenido: la explicatura y la implicatura. La primera consiste en "una combinación de rasgos conceptuales lingüisticamente codificados y contextualmente inferidos". ${ }^{11}$ En cambio, las implicaturas son las "premisas y conclusiones contextuales que el oyente tiene que incluir en el proceso interpretativo para mantener en pie el supuesto de que el hablante está siguiendo el Principio de Relevancia". ${ }^{2}$ Las implicaturas son supuestos que se deducen bien del contexto, bien de los conocimientos enciclopédicos que poseen los interlocutores o por inferencia a partir de la explicatura y el contexto. ${ }^{13}$ Para aclarar la diferencia entre ambos tipos de contenido, podemos reparar en este pequeño diálogo:

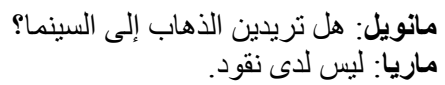

Como podemos observar, el enunciado proferido por María no es una respuesta directa a la pregunta que se le hace. Sin embargo, lo normal es que Manuel vaya a suponer que María está intentando ser relevante, esto es, intenta contestar a su pregunta de modo indirecto. Así pues, el joven activará ciertos supuestos a partir de los conocimientos enciclopédicos que posee en relación con la situación del discurso, que pueden ser:

a) El cine cuesta dinero.

b) Cada vez que María necesita dinero, yo se lo presto.

En vez de los anteriores supuestos, también puede activar otros distintos, como los siguientes:

a) El cine cuesta dinero.

b) Yo no tengo dinero y María nunca me pide dinero prestado.

\footnotetext{
${ }^{11}$ Sperber, D. y Wilson, D.: La relevancia, Visor, Madrid, 1994, 226.

${ }^{12}$ Leonetti, M. "Implicaturas generalizadas y relevancia", Revista Española de Lingüística, 23, 1 (1993), 107-139.

${ }^{13}$ Escandell Vidal, M. V.: Introducción a la pragmática, Ariel, Barcelona, 1996, 125.
} 
Tales supuestos servirán de premisa para que Manuel deduzca, en función de la elección que haga -guiado por la situación del discurso, por cierto-, una de las dos siguientes conclusiones implicadas:

1. María me pide que la invite al cine.

2. María rechaza la propuesta.

A pesar de que la implicatura está condicionada por la forma proposicional del enunciado, es evidente que estamos ante un contenido que se obtiene mediante la activación de procesos puramente inferenciales. El procesamiento de los elementos lingüísticos se produce, por lo tanto, en la explicatura. A pesar de que "la comprensión es un proceso on-line, y las hipótesis sobre las explicaturas se elaboran en paralelo, sobre un fondo de expectativas susceptibles de ser revisadas o elaboradas al tiempo que el enunciado vaya desplegando su auténtico significado", ${ }^{14}$ en la fase de elaboración de la explicatura, se pueden distinguir tres subtareas básicas:

a) Desambiguación.

b) Asignación de referente.

c) Enriquecimiento.

Como se ha consignado anteriormente, en la explicatura se combina lo lingüístico con lo inferencial. Así, si volvemos al primero de los tres enunciados aducidos al principio de esta sección, veremos que la homonimia relacionada con el lexema (رسالة) quedará resuelta con la desambiguación, puesto que el significado de esta palabra se orientará en un sentido u otro, en función de si se está hablando en la universidad o en una oficina de correos, por ejemplo. El problema de los segmentos vagos o indeterminados se resolverá básicamente en la fase correspondiente a la tercera subtarea, la cual posee un carácter eminentemente inferencial. ${ }^{15} \mathrm{~A}$ los elementos vagos no se les puede asignar referencia directamente en la fase b) sin pasar antes por la c), sencillamente porque este procedimiento necesitaría, tal como habíamos consignado anteriormente, de cierta perspectiva, que solamente se puede determinar por inferencia mediante enriquecimiento. De este modo, si en el segundo enunciado, el segmento (ماز الت صغيرة جدا) puede abarcar una franja tan amplia de la realidad externa, como ya sabemos, su dominio quedará enormemente reducido si disponemos de la información de que se está hablando, por ejemplo, de la posibilidad de que una persona se independizara de la casa de sus padres. Combinando, mediante enriquecimiento, este supuesto con la información enciclopédica que tenemos almacenada en la memoria sobre las edades a las que las personas suelen independizarse en nuestra cultura, conseguiremos poner una horquilla adecuada de valores reales a la expresión señalada (que, por la naturaleza que poseen tales términos, nunca podrán ser únicos), fijando así su referente. De la misma forma, los

${ }^{14}$ Wilson, D. y Sperber, D.: "La teoría de la relevancia”, Revista de Investigación Lingüística, 7 (2004), 237-286.

${ }^{15}$ Cfr. Sperber, D. y Wilson, D.: La relevancia, 228-239. 
segmentos indeterminados, como en el caso de (كتابك) en el tercer ejemplo, concretarán su sentido mediante enriquecimiento, si disponemos de los supuestos situacionales correctos y los combinamos con la información enciclopédica adecuada.

Los tres fenómenos de opacidad semántica que en esta ocasión nos incumben, pueden originar hilaridad, si se dan las circunstancias apropiadas para ello, tal como tendremos ocasión de ver en las siguientes secciones de nuestro estudio.

\section{AMBIGÜEDAD Y HUMORISMO}

Como hemos visto en la sección anterior, la ambigüedad suele originarse en la homonimia, esto es, en la existencia de un elemento interpretable en más de un sentido. Se trata, por lo tanto, de un fenómeno que:

"Sólo existe para el receptor; en lo que al emisor se refiere, él sabe exactamente lo que contiene su mensaje; con la excepción de algunos casos precisos (juegos de palabras, etc.), el mensaje transmitido no es, pues, ambiguo". ${ }^{16}$

De ahí que durante el proceso de interpretación se procure siempre conceder a los segmentos homónimos la lectura que les resulte más relevante. Para ello, el receptor se apoya en factores de diversa naturaleza. Los más inmediatos son los de carácter eminentemente lingüístico. De este modo, si una palabra como (زهر) se presta en árabe a expresar más de un sentido, la correcta selección del contenido que puede transmitir se basará, en cada caso, en la naturaleza semántica de los elementos lingüísticos con los que combina. Así, los criterios de selección que posee este lexema en cada una de sus vertientes significativas ayudarán a determinar la interpretación adecuada que ha de recibir en dos enunciados como los siguientes:

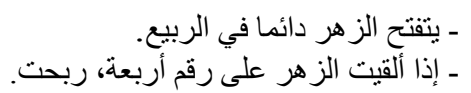

En caso de que las posibilidades de combinación no resulten suficientes para despejar la ambigüedad, el receptor recurrirá a otros criterios relacionados con la situación del discurso: el tema del que se habla, los participantes en el diálogo, los conocimientos compartidos, etc. puesto que:

"Every type of activity or language game possesses a corresponding inferential framework, i. e. specific expectations as to the function which a specific expression fulfills in specific context. This context, then, also delimits our interpretation, so as to obviate the possibility of semantic ambiguity". ${ }^{17}$

Así pues, este tipo de información será, en tal supuesto, lo único que podrá orientar el sentido que posee la palabra (زه), por ejemplo, en otro enunciado como el siguiente:

\footnotetext{
${ }^{16}$ Gingras, R.: "Para acabar con cierta ambigüedad léxica", Langues et Linguistique, 21 (1995), 91-105.

${ }^{17}$ Fredsted, E.: "On semantic and pragmatic ambiguity", Journal of Pragmatics, 30 (1998), 527-541.
} 


$$
\text { ـ كنت أحدثه و الزهر بيدي. }
$$

En este caso, la acepción que se seleccione dependerá, en una medida u otra, de si quien profiere el enunciado es, por así decirlo, un florista o jugador en un casino.

Siendo así la situación, cabe preguntarse sobre lo que suele fundamentar el humorismo en los enunciados que encierran cierto grado de ambigüedad. Teniendo en cuenta los mecanismos de desambiguación más recurrentes que acabamos de mencionar, es fácil observar que en este tipo de discurso hilarante el emisor intenta siempre bloquear o inutilizar el conjunto de mecanismos en los que puede apoyarse el receptor para llevar a cabo la adecuada interpretación del mensaje. Se trata, pues, de una especie de ambigüedad intencionada en la que "words are not intended to have only a single meaning and context-congruent meaning turns out to have very little to do with the true meaning of the joke ${ }^{.1} \cdot{ }^{18} \mathrm{El}$ primer paso es, por lo tanto, anular la función desambiguadora que puede desempeñar el contexto o la situación del discurso. Para aclarar esta idea, podemos reparar en el siguiente texto:

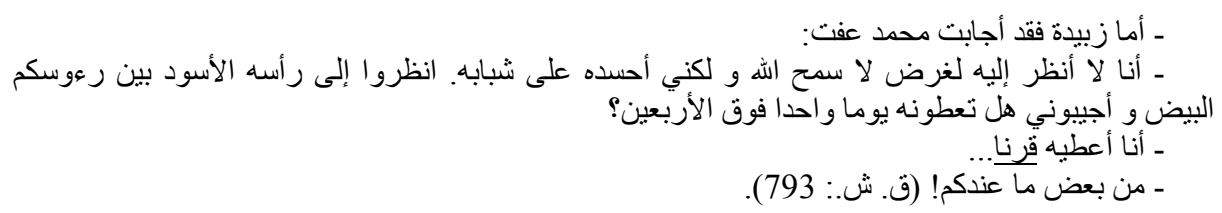

La clave del humor reside aquí en la homonimia del lexema (قرن), que, como bien se sabe, puede significar tanto (siglo) como (cuerno). Para crear comicidad, el autor ha procurado inutilizar los mecanismos de desambiguación de la palabra implicada, trayendo a colación una serie de lexemas o supuestos lingüísticos que evocan las dos acepciones que posee. Así, en relación con cada uno de esos significados, se mencionan las palabras (شباب، يوم، الأربعين) y (رأس), respectivamente. Con ello, el receptor no puede determinar el sentido exacto que se quiere transmitir con el uso de la voz (قرن) en esta situación y en este contexto.

Para que haya humor, el bloqueo de los supuestos originados por el contexto o la situación del discurso ha de ir acompañado, además, de la infracción de cierta regla. En nuestro corpus hemos observado tres: infringir la norma de cortesía, transgredir la coherencia semántica entre los componentes del enunciado o violar el principio de convencionalidad en relación con el uso de algún término. A continuación, analizamos detalladamente cada uno de estos tres mecanismos.

\section{1. EL USO DE UNA EXPRESIÓN INSOLENTE O COMPROMETEDORA}

El hablante recurre en este caso a la anfibología para evitar las consecuencias que le puede acarrear el uso de una expresión socialmente comprometedora. De esta forma, se escuda en la responsabilidad que asume el receptor al optar por una de las

${ }^{18}$ Vaid, J. et al.: "Getting a joke: the time course of meaning activation in verbal humor", Journal of Pragmatics, 35 (2003), 1431-1449. 
interpretaciones posibles de un segmento ambivalente, para hacerle también partícipe de las consecuencias interpretativas de dicho segmento. En el enunciado que venimos comentando, el emisor aprovecha el bloqueo de los supuestos contextuales relacionados con las dos acepciones que posee la palabra (قرن), para insultar a su compañero. En tal caso, la responsabilidad de la interpretación no puede recaer íntegramente en el emisor, sino que también la comparte con él el propio receptor, puesto que es éste quien opta, en última instancia, por dar prioridad interpretativa a la acepción de (cuerno) sobre la de (siglo). Este mismo hecho lo podemos observar también en el siguiente texto:

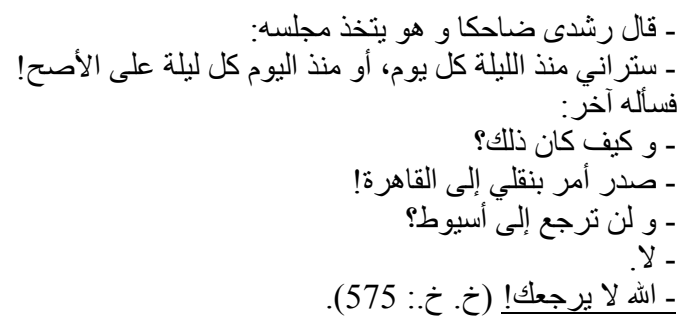

Como sabemos, la expresión subrayada se suele usar en árabe moderno normalmente en tercera persona- para expresar el vehemente deseo que tiene el hablante de que una mala persona, ya ausente, no vuelva al lugar del que se había marchado. No obstante, la diferencia semántica que existe entre el uso normal que posee el verbo (رجع) en árabe y el sentido que suele comportar en la expresión lexicalizada queda sin efecto, debido a los factores de contexto y situación especiales que en este caso lo envuelven: la complementación circunstancial que le acompaña en una oración precedente, el nuevo sentido positivo que pragmáticamente adquiere la expresión en su conjunto en este nuevo entorno, etc. En definitiva, todo ello hace que la posible interpretación insultante del segmento subrayado tampoco pueda considerarse, pues, responsabilidad exclusiva del emisor.

Otra variante de este resorte se puede detectar, asimismo, en los casos en los que uno de los interlocutores aprovecha un fallo cometido por otro, para castigar una actitud que en él no aprueba: una vanidad flagrante, un insulto previo, etc. Nos puede servir de ejemplo el siguiente enunciado:

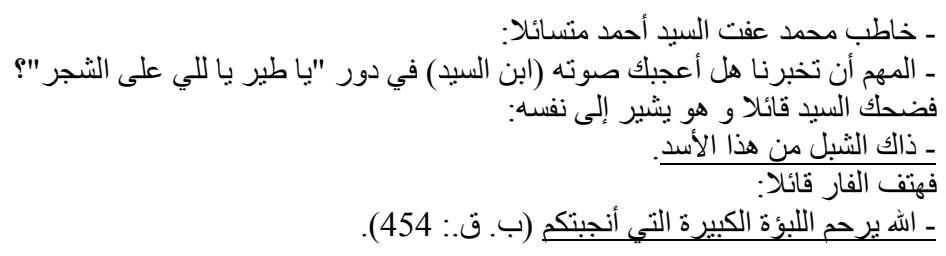

Como habremos podido observar, en este ejemplo el segundo interlocutor aprovecha un error argumentativo que comete el primero al vanagloriarse de la belleza de la voz de su hijo, usando la frase hecha que aparece subrayada en el texto. Para vengarse de su contrincante, que muestra una actitud claramente altiva, aquél, 
en alusión a la madre de éste, utiliza el segmento (اللبؤة الكبيرة), que aparenta tener un sentido positivo -puesto que va en la misma línea argumentativa elegida por su adversario- a pesar de ser realmente insultante. Como sabemos, la palabra (لبؤة) suele encerrar un insulto bastante fuerte en árabe moderno, cuando se usa en referencia a cualquier mujer. En todo caso, el receptor también compartiría aquí la responsabilidad de la interpretación insultante de este lexema, puesto que si él en sus argumentos dice de sí mismo que es (أسد), su madre sería, siguiendo la misma lógica argumentativa, (لبؤة).

\section{2. LA VIOLACIÓN DE LA CONGRUENCIA DEL TEXTO}

Dentro del texto, las palabras suelen tejer redes o estructuras de representación semántica que las entrelazan. Dichas redes son esenciales para el receptor, puesto que rigen y orientan la tarea de interpretación de los mensajes. Por regla general, la interpretación de las palabras homónimas ha de realizarse siempre de acuerdo con la congruencia del texto en el que son intercaladas, a menos que haya suficientes razones que nos obliguen a obrar de otra manera. Estas redes las pueden integrar, por otro lado, los elementos que forman parte de la situación del discurso. De este modo, si en un contexto en el que aparecen palabras como café, agua, refresco, etc. concurre una palabra homónima como bote, el sentido más accesible que se le dará va a ser, seguramente, el de "pequeño recipiente" y no el de "pequeña embarcación" o "salto". El mismo resultado lo obtendremos si dicha palabra es proferida en una situación de discurso en la que un grupo de amigos está hablando en una cafetería. En este último caso, la creación de la congruencia textual correrá a cargo de los elementos del discurso y no de la concurrencia del lexema implicado con otras palabras pertenecientes a un mismo campo semántico.

En el discurso humorístico, lo que se observa en los enunciados que echan mano de este segundo mecanismo, es la existencia de una especie de choque entre dos congruencias, que confluyen en una misma palabra o expresión ambivalente. $\mathrm{La}$ carga hilarante se debe básicamente en tales supuestos al hecho de que:

"The asymmetrical distribution of information in the joke concedes to or, rather, utilizes our 'one-track mind', so that when the second reading is disclosed we are totally unprepared, caught of guard, so to speak. Possibly, what enables such a manipulation of ambiguity is our tendency to save mental effort". ${ }^{19}$

Lo que sucede en este caso, es que en el texto aparece un lexema o una expresión de contenido anfibológico, en un entorno en el que la congruencia textual hace que en un primer momento se interprete en un sentido concreto. No obstante, el receptor no tarda en descubrir que el significado que el emisor le daba a dicha expresión es justamente el que antes no parecía ser el más apropiado. Veamos el siguiente ejemplo:

$$
\text { ـ ما الاسم الكريم؟ }
$$

\footnotetext{
${ }^{19}$ Giora, R.: "On the cognitive aspects of joke”, Jornal of Pragmatics, 16 (1991), 465-485.
} 


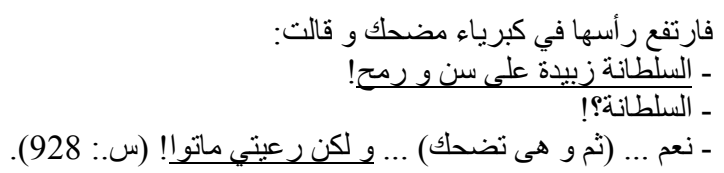

Como sabemos, a principios del siglo XX se usaba en Egipto la palabra (سلطانة) como fórmula de tratamiento para dirigirse o aludir a las cantantes famosas del país. El lexema poseía, pues, un sentido especializado, aparte de la acepción general que hasta hoy día sigue manteniendo. En el ejemplo que acabamos de citar, una de estas cantantes, ya vieja y demacrada, se presenta a un grupo de jóvenes, utilizando la palabra homónima. En un primer momento, la congruencia textual nos hace pensar en el significado relacionado con el mundo del espectáculo. No obstante, con la aparición de la palabra (رعية), que constituye otra congruencia o red de representación semántica, la primera interpretación del lexema queda sustituida por la de (reina). Justamente en este momento, nos damos cuenta de que la mujer utilizaba la palabra (سلطانة) en el sentido que habíamos descartado, para hacer que nos riéramos.

En otras ocasiones el choque entre las dos congruencias se debe realmente a una diferencia entre los elementos que constituyen el contexto, por un lado, y los que integran la situación del discurso, por el otro. Para aclarar esta idea, hemos de advertir que por contexto entendemos el conjunto de unidades lingüísticas que componen el entorno en el que se inserta el lexema implicado, en tanto que con el término situación de discurso aludimos a los elementos extralingüísticos que envuelven el acto de habla en sí mismo. Entran a formar parte de la situación del discurso una variada gama de hechos, tales como el lugar y el momento en los que se habla, las personas que entre sí entablan la conversación, los conocimientos compartidos, etc.

En los enunciados humorísticos basados en el choque entre contexto y situación de discurso, la palabra homónima se inserta normalmente en un entorno lingüístico cuya congruencia favorece la interpretación en un sentido distinto al que se haría si el receptor dispusiera de cierta información privilegiada. En tales supuestos, el emisor intenta dar a sus palabras dos lecturas bien distintas, una falsa y engañosa, para los oyentes con los que no mantiene una relación de complicidad, y otra veraz, para un receptor allegado, con el que comparte información confidencial. Para entender la naturaleza de esta categoría de enunciados, podemos fijarnos en un ejemplo como el que a continuación citamos:

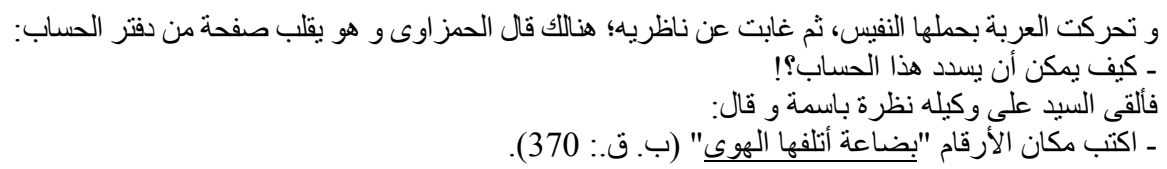

En el segmento subrayado, la interpretación inmediata que puede tener la palabra (الهوى) -especialmente en el lenguaje hablado, donde es frecuente la desaparición de la hamza final- será algo así como (las inclemencias del tiempo), (el viento), etc. Esta interpretación va en consonancia con la congruencia creada por las 
palabras (بضاعة) y (أتلف), que la acompañan. No obstante, el ayudante, igual que el lector de la obra, sabe muy bien que la acepción con la que el emisor utiliza esta voz es la de (amor), puesto que comparte con su interlocutor la información privilegiada de que la mercancía a la que se está refiriendo ha sido regalada a una de las amantes del dueño del local.

Otra variedad de la violación de la congruencia se produce cuando, con el cambio de turno de palabra en un diálogo, el nuevo emisor crea otra red de representación semántica, utilizando, al mismo tiempo, un lexema ambivalente cuyas vertientes guardan una estrecha relación con ambas congruencias:

$$
\begin{aligned}
& \text { ـ لا خوف عليك من هذه الناحية ... } \\
& \text { فقال العجوز و هو يرفع الكأس إلى فيه: }
\end{aligned}
$$

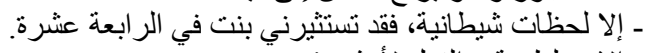

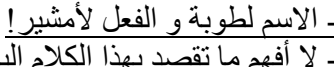

$$
\begin{aligned}
& \text { - لا أفهم ما تقصد بهذا الكلام البارد (س.: 837). }
\end{aligned}
$$

En este caso, el adjetivo (بارد) -que posee dos acepciones distintas, esto es, (frío) e (inoportuno), respectivamente- se introduce en un contexto en el que un primer emisor crea una congruencia relacionada con el primer sentido, al mencionar palabras como (طوبة) y (أمشير), que a su vez aluden a dos meses del calendario copto conocidos por la inclemencia del clima. Acto seguido, el segundo hablante, crea una congruencia distinta, puesto que utiliza la palabra implicada en la función de modificador del sustantivo (كلام), en cuya inmediación el adjetivo ha de ser interpretado inevitablemente en el segundo sentido. Un caso ligeramente distinto a esto, lo podemos encontrar en este otro ejemplo:

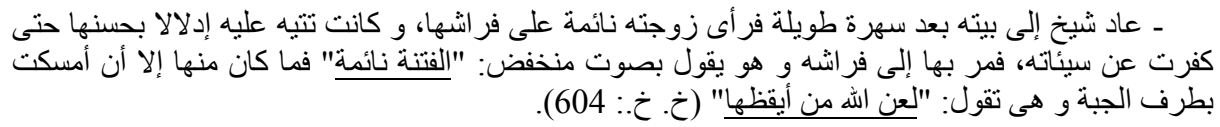

El choque de congruencias corre en este caso a cargo del segundo significado que tiene la palabra (الفتنة) -esto es, (sedición), en vez de (tentación)- y que nos lo evoca en este enunciado el sentido exacto que en la tradición árabe posee la famosa frase que pronuncia la mujer.

\section{3. LA VIOLACIÓN DEL PRINCIPIO DE CONVENCIONALIDAD SEMÁNTICA}

Uno de los componentes básicos de las lenguas naturales es el relacionado con las unidades fraseológicas o estructuras fijas. Lo característico en estos elementos lingüísticos es la nueva dimensión que desde el punto de vista semántico adquieren, dentro del conjunto, los constituyentes que los integran. Una vez aceptada la estructura como expresión fija, el hablante ya no dispone de la libertad habitual de utilizar ninguno de sus elementos en el sentido que de modo individual puede expresar en la lengua. Ello se debe al hecho de que "en el habla cotidiana, nos resistimos a la multiplicación de los significados; nos adherimos al principio de 
convencionalidad y guardamos el principio 'una forma - un significado ${ }^{\text {,', }} \cdot{ }^{20} \mathrm{Es}$, por lo tanto, una estrategia que tienen las lenguas para garantizar una comunicación fluida y lo más inequívoca posible entre sus usuarios. Según este principio de convencionalidad, "one should use the conventional term to express a given meaning, and one should not use a term with a conventional sense to mean something different (unless the speaker wishes to implicate something else)". ${ }^{21}$ Una de las consecuencias que puede acarrear el uso de estas expresiones en un sentido diferente al que le viene dado es precisamente la creación del humor, tal como podemos apreciar en el siguiente texto:

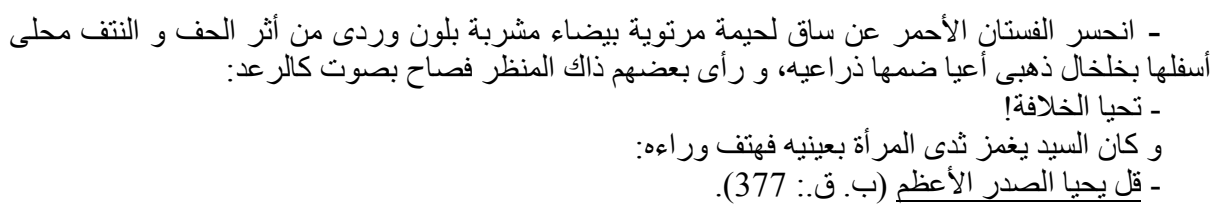

En este ejemplo, el emisor de la oración subrayada rompe la convencionalidad semántica de la secuencia (الصدر الأعظم), al recuperar el significado original de una expresión que se usa para aludir a una de las máximas autoridades del chiísmo, dentro de la religión musulmana. No obstante, lo que realmente sustenta el humorismo en este caso, es la ambivalencia que sigue teniendo el término, al ir acompañado en el mismo texto de la palabra (خلافة). La dilogía es, en tales supuestos, una condición sine qua non para originar la hilaridad dentro del enunciado. Otro ejemplo de este tipo de ambigüedad humorística lo podemos ver también en este otro texto:

$$
\begin{aligned}
& \text { ـ مساء الخير يارجال } \\
& \text { فرحب رياض بتحيتهاء الخيز فال بحر ارة: }
\end{aligned}
$$

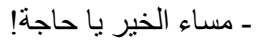

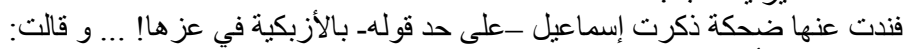

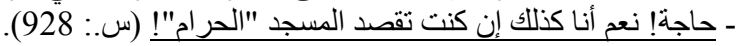

Por lo que, en su calidad de receptores privilegiados, saben los lectores acerca de la historia del personaje que profiere el segmento subrayado, la unidad fraseológica implicada pasa a tener aquí un sentido claramente sexual, sin dejar de aludir del todo a la mezquita más sagrada de los musulmanes. Así, un receptor desprevenido podría interpretar la expresión en el sentido original que posee, en tanto que otro que disponga de la información relacionada con el pasado desenfrenado de esta mujer, captaría enseguida las segundas intenciones que encierran sus palabras. Una vez más, la complicidad creada entre tal receptor y el personaje que emite el enunciado sustentará la comicidad del texto.

\footnotetext{
${ }^{20}$ Nerlich, B y Chamizo Domínguez, P. J.: "Cómo hacer cosas con palabras polisémicas: El uso de la ambigüedad en el lenguaje ordinario", Contrastes: Revista Interdisciplinar de Filosofia, 4 (1999), 77-96.

${ }^{21}$ Lehrer, A.: "Polysemy, conventionality, and the structure of the lexicon", Cognitive Linguistics, 1-2 (1990), 207-246.
} 
En todos los casos que hemos analizado hasta el momento, podemos observar la existencia de una superposición intencionada de significados, que el emisor plantea a sus oyentes. La suerte del enunciado humorístico dependerá aquí de si el receptor se percata o no de la multiplicidad de sentidos que se le presentan. No obstante, en otras ocasiones ocurre justamente lo contrario, esto es, el receptor se da cuenta de la existencia de más significados que los que el hablante pretende transmitir. Es una especie de trampa en la que involuntariamente cae el emisor, puesto que por la forma en la que está constituido el mensaje:

"Las inferencias del oyente llegan a más profundidad que las intenciones semánticas del hablante. Y la profundidad inferencial en la que se sumerjan los interlocutores depende lo mismo de la multiplicidad de significados disponibles que de la situación y la función de la interacción". ${ }^{22}$

Lo que confiere hilaridad a este tipo de enunciados es el sentimiento de superioridad que invade al receptor al sorprender al interlocutor desprevenido, cayendo en su propia trampa. Dos condiciones han de cumplirse, pues, para que el humorismo se origine en tal supuesto:

1. Que el oyente se dé cuenta de la superposición de significados.

2. Que uno de los posibles sentidos sea comprometedor para el hablante.

Nos puede servir de ejemplo el siguiente texto:

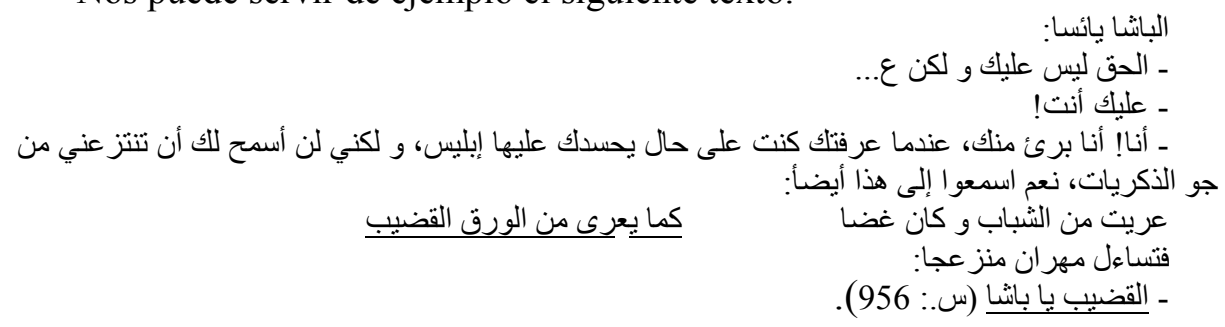

La comicidad que se percibe en este texto se debe fundamentalmente a la homosexualidad no declarada del hombre acaudalado que recita el verso. Con esta réplica, el joven le advierte del error que acaba de cometer al usar la palabra (فضب) en esta situación y en este contexto. Como sabemos, esta palabra se puede usar en árabe para referirse, entre otras cosas, al miembro viril. El contexto en el que aparece puede favorecer, además, su vertiente sexual, dejando así al descubierto al incauto emisor.

\section{INDETERMINACIÓN SEMÁNTICA Y HUMORISMO}

Las unidades del lenguaje son elementos que poseen una semántica poco precisa que, mediante enriquecimiento, ha de ser completada y ajustada por el

\footnotetext{
${ }^{22}$ Nerlich, B y Chamizo Domínguez, P. J.: "Cómo hacer cosas con palabras polisémicas: El uso de la ambigüedad en el lenguaje ordinario", 81 .
} 
receptor a los requisitos de relevancia óptima que, en circunstancias normales, subyace a los enunciados que se intercambian durante la comunicación. Varios factores influyen en este proceso de enriquecimiento y pueden afectar, por ende, a los valores que finalmente se dan a las señales comunicativas. En líneas generales, el oyente, al recibir una señal transmitida por un emisor concreto, ha de disponer de los datos necesarios para contestar a tres preguntas esenciales cuyas respuestas le capacitarán para realizar la adecuada interpretación de los enunciados:

1. ¿De qué se habla?

2. ¿Con qué intención?

3. ¿Cómo se configura el mensaje?

Si fracasa en conseguir la respuesta correcta a cualquiera de estas preguntas, no podrá llegar a la información exacta que se le quiere transmitir. Contestarlas eficientemente es el preludio del proceso de enriquecimiento que el receptor necesita realizar para salvar las lagunas existentes tras la descodificación. De ahí que en los enunciados humorísticos basados en la indeterminación de las unidades del lenguaje empleadas se perciba siempre una infracción que pretende bloquear la respuesta a cualquiera de estas tres preguntas. En este sentido, observaremos siempre la existencia de uno de los siguientes mecanismos:

1. Un intento, realizado normalmente por el emisor, de ocultar alguno de los elementos necesarios para dar respuesta a cualquiera de las tres preguntas mencionadas.

2. Un injustificado fracaso, por parte del receptor, de alcanzar una respuesta eficiente a una de dichas preguntas.

Cada una de estas tres preguntas se relaciona con una categoría distinta de indeterminación: la referencial, la ilocutiva y la codificadora. A continuación analizaremos cada uno de estos tres tipos.

\section{1. INDETERMINACIÓN REFERENCIAL}

Este tipo de indeterminación bloquea la imprescindible tarea de enlazar lo lingüístico con lo extralingüístico, esto es, saber a qué hechos exactos de la realidad externa se refieren las palabras empleadas en el enunciado. No hay que confundir aquí vaguedad e indeterminación. En el caso de los términos vagos lo primero que hay que adoptar es una perspectiva que nos ayude a delimitar una horquilla de valores entre los que podamos ubicar la referencia exacta de los signos. Esta horquilla será siempre subjetiva, de modo que lo que para unos puede entrar a formar parte del dominio extralingüístico de un signo dado utilizado en una situación concreta, no pertenecerá para otros a dicho dominio en las mismas circunstancias descritas. Habrá siempre, además, tal como hemos establecido en su momento, zonas periféricas que no gozarán de la unanimidad de todos los 
receptores. En el caso de los términos indeterminados no existirán nunca tales periferias, puesto que o se consigue determinar la referencia exacta o se fracasa en hacerlo. Los criterios seguidos serán, por otra parte, siempre objetivos, de tal modo que si se dispone de una misma información, la referencia será siempre idéntica para los distintos receptores implicados en el diálogo.

Como hemos afirmado anteriormente, el humor relacionado con este tipo de unidades lingüísticas ha de basarse en uno de los dos siguientes mecanismos: un intento de ocultar alguno de los datos que ayudan a determinar la referencia exacta del signo o un injustificado fracaso por parte del receptor en hacerlo. El siguiente texto nos puede servir como ejemplo del primero de estos dos supuestos:

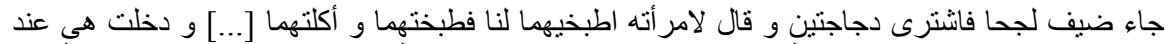

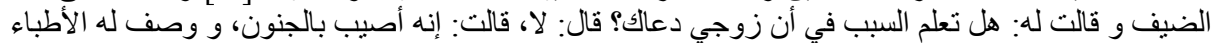

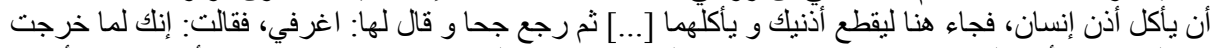

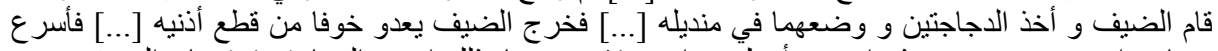

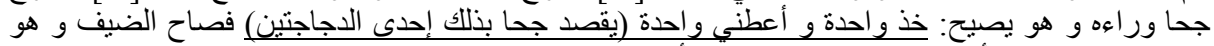

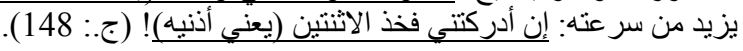

Está claro que el malentendido radica en este caso en la distinta información de la que parte cada uno de los dos interlocutores a la hora de determinar la referencia exacta de las palabras implicadas. Si ambos dispusieran de una misma información desaparecería el malentendido, puesto que las palabras pasarían a aludir, consecuentemente, a un mismo objeto para ambas personas. Ha sido esencial para la creación del humor en este texto lo que hizo la astuta mujer del anfitrión. Su argucia ha contribuido a bloquear los datos relacionados con la respuesta a la primera pregunta, por lo que cada uno de los dos personajes fracasa en determinar de qué está hablando exactamente el otro. Este mismo hecho lo podemos observar también en el siguiente texto:

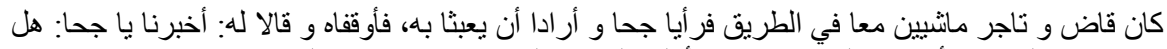

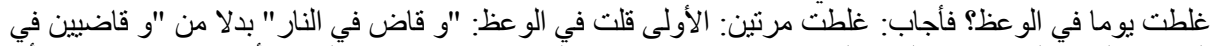

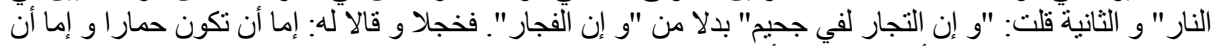

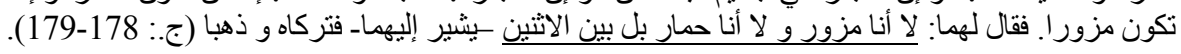

Lo que hace el predicador aquí es colocar la palabra (الاثثين) en un entorno en el que, dependiendo de si realiza una función anafórica o no, puede aludir simplemente a un hipotético (مزور) y un presunto (حمار) o referirse, en cambio, al juez y al mercader como tales. Algo distinto sucede en el siguiente texto, donde la responsabilidad recae en el receptor y no en el hablante:

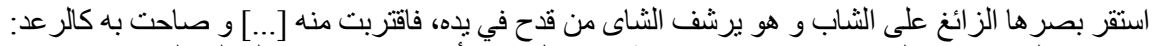

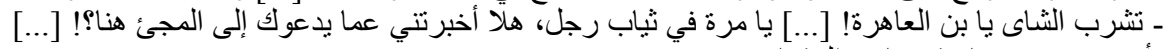

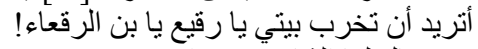

$$
\begin{aligned}
& \text { فقال لها الثشاب مرتعدا: }
\end{aligned}
$$

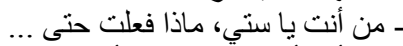

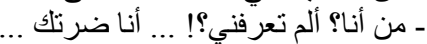

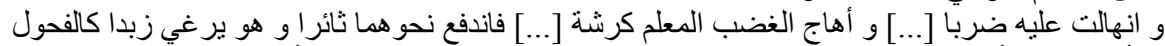

$$
\begin{aligned}
& \text { [...] و أجبرت المر أة تحت ضغط زوجها على ترك غريمها [...] فجن جنونها [...] و أمسكت بتلابيب المعلم [...] }
\end{aligned}
$$




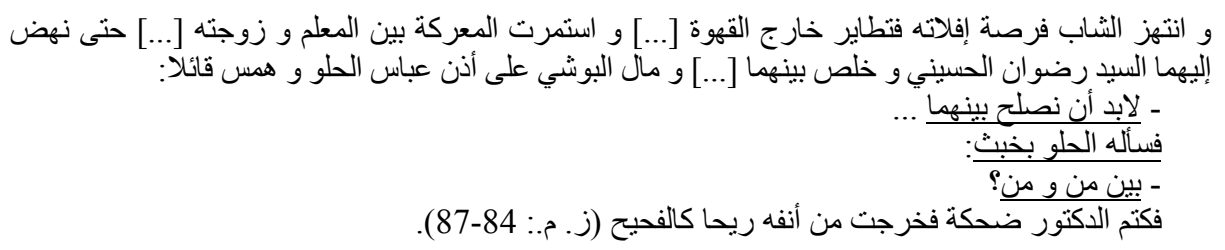

Aquí, el segundo personaje aprovecha la indeterminación del pronombre personal para crear la comicidad. El primer interlocutor encomienda la determinación de referencia del pronombre (ه) a cuestiones culturales y sociales vigentes: es normal intervenir en la reconciliación de un marido con su mujer, si surgen problemas entre ambos, pero no así entre una pareja de homosexuales. Este hecho es suficiente, por lo tanto, para que el receptor del primer enunciado entienda que el pronombre utilizado hace referencia al dueño del café y su mujer y no a aquél y su joven amante. La base del humorismo se encuentra, pues, en el hecho de que el receptor fracasa en reconocer, o mejor dicho, hace caso omiso a este dato, que le ayudaría a determinar, mediante enriquecimiento, la referencia exacta del pronombre personal implicado.

\section{2. INDETERMINACIÓN ILOCUTIVA}

Una vez identificada la forma proposicional del enunciado, el receptor tiene que llegar a determinar también la actitud o la intención con la que el emisor emplea sus palabras. Es un paso esencial en el proceso de interpretación, puesto que con una misma forma proposicional se puede comunicar una variada gama de sentidos, en función de la actitud adoptada por el hablante en cada caso. Esta actitud, que en los estudios pragmáticos se conoce con el nombre de fuerza ilocutiva:

"No es una propiedad ligada exclusivamente a la forma lingüística utilizada, sino el producto de la combinación de varios factores: es la interacción entre el conocimiento lingǘstico y el conocimiento extralingüístico lo que permite caracterizar la contribución como perteneciente a un tipo u otro de acto de habla". ${ }^{23}$

Igual que en los demás tipos de indeterminación, aquí también la responsabilidad del uso chistoso del lenguaje puede recaer tanto en el emisor como en el receptor. En el primer caso, es imprescindible la elaboración de una trampa semántica que "consiste en actualizar el término constituyente de la estructura (o perfilar su sentido), de modo que la lectura o el script prototípico sólo sea posible. El paso siguiente es ofrecer la clave de reinterpretación". ${ }^{24}$ Es justamente la estrategia que podemos percibir en el siguiente ejemplo:

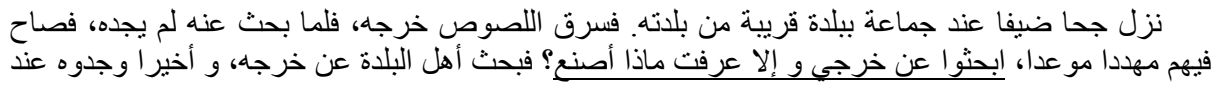

${ }^{23}$ Escandell Vidal, M. V.: La comunicación, Gredos, Madrid, 2005, 71.

${ }^{24}$ Wilk Racieska, J.: "Semántica del humor. Condiciones semánticas de crear y disimular la trampa en los chistes lingüísticos”, Contextos, XVII-XVIII/33-36 (1999-2000), 209-221. 
جماعة من اللصوص فأحضروه ثِثم سأله أحدهم: إذا لم نجد خرجك فماذا كنت تصنع؟ فقال جحا: عندي بساط قديم، أعمل منه خرجا! (ج.: 175).

Como habremos podido observar, el uso del primer enunciado de Ŷuhā en la situación descrita por la anécdota, le confiere una función evidentemente amenazadora. Aquí, el oyente se olvida de la existencia de una posible lectura aseverativa, que en un primer momento no se ve favorecida por las circunstancias que rodean la enunciación. En la segunda parte del chiste, las nuevas palabras del protagonista desvelan las verdaderas intenciones, que se ocultan bajo apariencia conminativa, aflorando así el sentido aseverativo del primer enunciado. La base del humor se encuentra, en este caso, en el contraste que se percibe entre las dos interpretaciones.

Hemos de advertir, sin embargo, que en ocasiones los conocimientos compartidos entre emisor y receptor son los que nos pueden desvelar la segunda lectura. En tales casos, el sentimiento de complicidad que se crea entre las personas implicadas en el diálogo, es lo que suele sustentar el humor en el discurso:

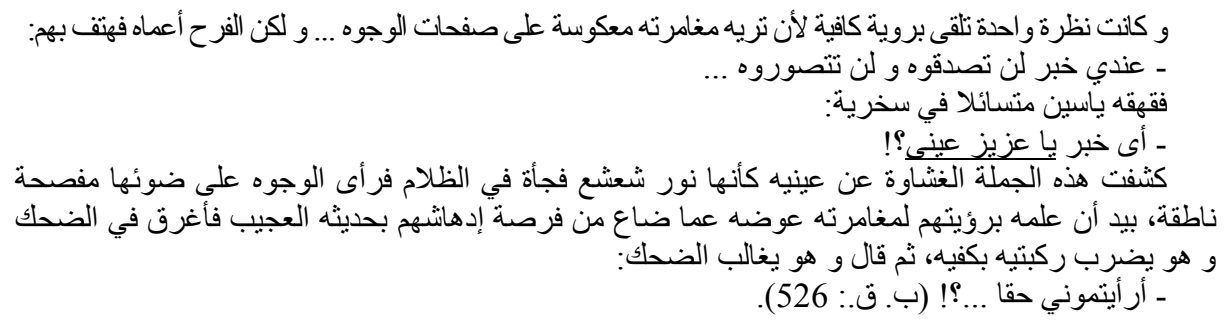

En este ejemplo, el hermano mayor utiliza el título de la famosa copla egipcia que canta el niño al final de su aventura con los soldados ingleses- no con una función estrictamente interpelativa, sino más bien con el objeto de comunicar a Kamāl, de forma muy resumida, que la familia está al corriente de todos los detalles del acontecimiento que él viene a contarles.

Cuando el responsable de la creación de la comicidad es el receptor y no el emisor, lo único que se percibe es una mala interpretación -intencionada o no- de la actitud proposicional que envuelve al enunciado. Un caso típico es el que se deriva de la diferencia entre el valor pragmático de una enunciación y su uso mencionado: $:^{25}$

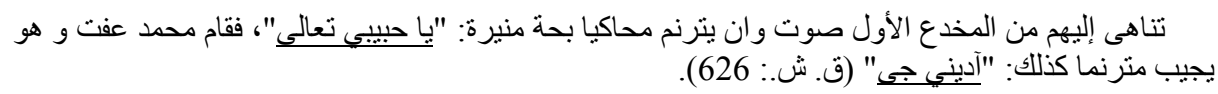

El oyente interpreta -intencionadamente mal en este ejemplo- las palabras de la canción entonada por la mujer, no como tal sino como una interpelación que se le hace; este hecho nos lo desvela el enunciado jocoso que profiere. En este error aparente descansa el humorismo en el texto que acabamos de citar.

${ }^{25}$ Cfr. Gutiérrez Ordóñez, S.: De pragmática y semántica, 200. 


\section{3. INDETERMINACIÓN CODIFICADORA}

Con esta denominación aludimos a la posible indeterminación semántica derivada de la forma elegida por el emisor para configurar la señal lingüística que utiliza. Puede afectar a ambas vertientes del signo: el significante y el significado. En el primer caso, la indeterminación se manifiesta en la elipsis de ciertos elementos cuya recuperación se encomienda a los procedimientos inferenciales que ha de aplicar el receptor durante el proceso de interpretación del mensaje. En el segundo supuesto, la indeterminación se relaciona con el modo de configurar la señal o bien como una expresión de sentido directo y literal o bien como una secuencia de semántica indirecta y figurativa. Esta categoría de indeterminación tiene que ver, por lo tanto, con dos fenómenos lingüísticos concretos: la elipsis, por un lado, y el uso figurado del lenguaje, por el otro.

\section{3. A. LA ELIPSIS DE SECUENCIAS FÁCILMENTE RECUPERABLES}

Siguiendo el principio de economía del lenguaje, el emisor suele elidir, en circunstancias normales, todas aquellas partes de la señal que pueden ser restituidas inferencialmente. Sin embargo, este hecho puede ser aprovechado, tanto por el emisor como por el receptor, para crear enunciados humorísticos. Así, el hablante puede echar mano de este recurso para formular enunciados que pueden ser interpretados de distintas formas, en función del procedimiento de restitución aplicado, tal como podemos apreciar en el siguiente texto:

$$
\begin{aligned}
& \text { فرك على مهران يديه في حبور و هو يقول: }
\end{aligned}
$$

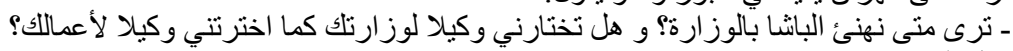

$$
\begin{aligned}
& \text { فقال الباشا ضاحكا: } \\
& \text { ـ بل أعينك مدير العاما للسجون، إن مكانك الطبيعى هو السجن (س.: 878). }
\end{aligned}
$$

La recuperación de la parte elidida -como continuación del segmento subrayado- nos sugiere inferir tanto el significado de (en calidad de director) como el de (en calidad de preso). Si nos basamos única y exclusivamente en la primera parte del enunciado que profiere el futuro ministro, el sentido recuperado será el primero. Si partimos, en cambio, de la actitud adoptada por el emisor y la idea más accesible que nos puede evocar (estar en la cárcel), la elipsis se resolverá mediante la restitución del segundo. En otras ocasiones, la elipsis origina la creación de segmentos coincidentes en su forma con otras expresiones existentes en la lengua, y que transmiten otros valores totalmente distintos:

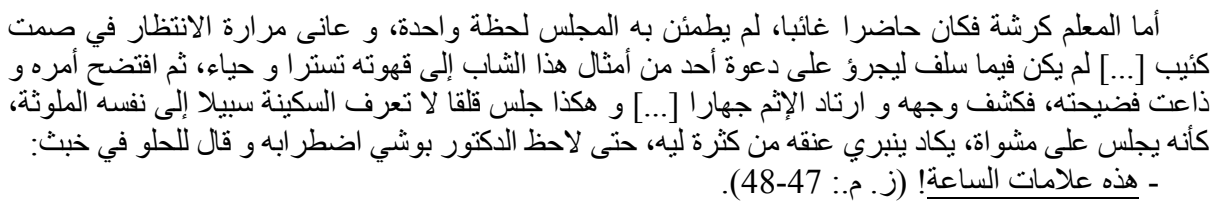


Como podemos ver, en la parte subrayada del texto va elidido el segmento que se refiere a la cita que unirá al dueño del café con el joven homosexual al que espera. La supresión de esta parte, fácilmente recuperable por inferencia, crea una secuencia coincidente con una expresión que en árabe significa (las señales del día del juicio final). La superposición de ambos sentidos es lo que da pie a la comicidad en este texto.

Por su parte, el receptor también puede ser responsable de la creación del humor, si de una forma inexcusable fracasa, aunque sea fingiéndolo, en restituir lo que se elide:

$$
\begin{aligned}
& \text { كان جحا في المسجد مع بعض أصحابه يتحدثون في شئ من التباهي عن العبادة و التهجد في الليل فسألوه: } \\
& \text { هل تقوم الليل يا جحا؟ قال: أقوم الليل لأبول ثم أعود إلى فئر اثي! (جئ. 175). }
\end{aligned}
$$

Los que aquí formulan la pregunta se basan en la situación y en el tema del que se habla, para elidir un segmento fácilmente deducible por las circunstancias que rodean el diálogo: para rezar. Sin embargo, la respuesta dada desvela que dicha secuencia no ha sido tenida en cuenta por el receptor durante el proceso de interpretación del mensaje, puesto que la pregunta fue entendida en un sentido más general del que realmente tiene.

\section{3. B. PISTAS DE LA INTERPRETACIÓN FIGURADA}

En el lenguaje figurado, se observa siempre una notable divergencia entre lo que se dice y lo que realmente se quiere comunicar. Durante el proceso de interpretación de este tipo de discurso, el receptor suele apoyarse en ciertas pistas para descartar el sentido literal del enunciado y pasar así a la consideración de una segunda lectura de sus palabras. La clave del éxito en tales casos radica siempre en hacer una interpretación lo más relevante posible de todas las unidades lingüísticas que integran el mensaje. Para los mentores de la teoría de Relevancia -y en contra de lo que se ha creído hasta el momento- las figuras retóricas (metáfora, sinécdoque, hipérbole, etc.) no suponen la violación de ninguna máxima griceana:

"Sino que son, simplemente, rutas alternativas para alcanzar la relevancia óptima. $\mathrm{Si}$ un enunciado se entiende literal, imprecisa o metafóricamente será algo que dependa del ajuste mutuo entre contenido, contexto y efectos cognitivos, en su esfuerzo para satisfacer la expectativa completa de relevancia del hablante". ${ }^{26}$

Los enunciados que se caracterizan por el uso figurado del lenguaje son imprecisos en la medida en que pueden aceptar dos lecturas, una inmediata, que el receptor, en función de supuestos de diversa naturaleza, ha de descartar, y otra mediata a la que tiene que llegar, guiado por una relevancia óptima del mensaje. Lo que sucede en los enunciados donde se combina humorismo y uso figurado del lenguaje es que el receptor se queda a medio camino en su proceso de interpretación, puesto que sólo realiza la lectura inmediata sin pasar posteriormente a la lectura verdaderamente relevante. $\mathrm{La}$ comicidad se basa entonces en el hecho de que con esto el receptor deja al descubierto

\footnotetext{
${ }^{26}$ Wilson, D. y Sperber, D.: "La teoría de la relevancia”, 259-260.
} 
una mermada capacidad cognitiva con respecto a los demás participantes en el diálogo. Veamos la siguiente anécdota que se cuenta de Ŷuhāa:

ـ كان يمضغ يوما قطعة من العلك (اللبان) في أحد المجالس، فدعوه لتناول الطعام. و لما جلس ليأكل أخرج

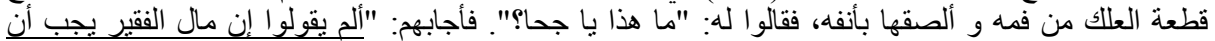
يكون نصب عنينيه!" (ج.: 115).

Lo que realmente nos hace reír en un caso como este es la torpeza manifestada a la hora de interpretar el mensaje. En este texto en concreto, el personaje no consigue darse cuenta de que es imposible, además de absurdo, poner en práctica lo que dicen literalmente las palabras. Esta imposibilidad de trasladar el contenido literal de la recomendación o el consejo al mundo real, obliga a un receptor de inteligencia media a pasar a otra lectura figurada: cuidar bien de lo que se tiene.

No obstante, el humor relacionado con esta categoría de enunciados no tiene por qué desvelar siempre una reducida capacidad cognitiva del receptor. En otras ocasiones puede suceder, incluso, justamente lo contrario: el perspicaz receptor se da cuenta de la existencia de unas segundas intenciones negativas que van disfrazadas bajo la apariencia de un uso figurado del lenguaje. Es el caso del humor que se detecta, por ejemplo, en el siguiente diálogo que tiene al-Sayyid Aḥmad con uno de sus amigos, tras una larga temporada de ausencia de sus veladas diarias:

$$
\begin{aligned}
& \text { على عبد الرحيم و هو يضحك: } \\
& \text { ـ سترى الآن وجو ها لم تر ها منذ خمس سنو ات ... . }
\end{aligned}
$$

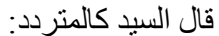

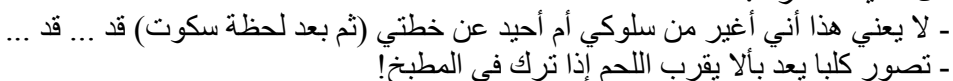

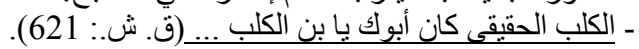

Aquí, el personaje implicado se da cuenta de la posible intención insultante de su interlocutor y decide atacarle por ello.

En otras ocasiones, el verdadero objetivo del receptor, al no pasar de la lectura inmediata a la mediata, es burlarse del emisor del enunciado:

$$
\begin{aligned}
& \text { ابتسمت، و هى ترفع حاجبيها في شئ من الارتباك، ثم قالت باقتضاب: }
\end{aligned}
$$

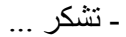

$$
\begin{aligned}
& \text { تنفس الرجل تتفسا عميقا ملأ به صدره العريض، ثم قال بحماس: }
\end{aligned}
$$

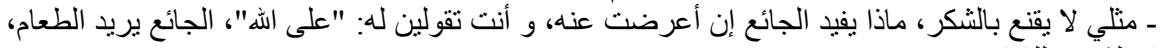

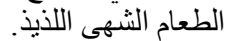

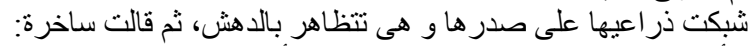

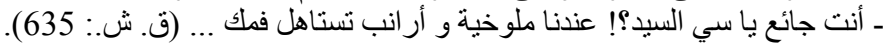

En realidad, esta actitud por parte del receptor puede obedecer a una variada gama de razones y realizar un sinfín de funciones pragmáticas. No obstante, lo que aquí nos interesa es recalcar el hecho de que ignorar las pistas que conducen a la segunda interpretación del enunciado por parte del receptor originará siempre humorismo en el discurso. Por su parte, el emisor también puede jugar con las 
pistas de interpretación para crear la hilaridad, si consigue neutralizarlas en el texto que formula. Veamos la siguiente anécdota que se cuenta de Ŷuhā:

اشتهى أن يأكل لحما فعملته زوجته و أكلته هى و عشيقهاو وضعت في الحلة خيار ا، و لما جاء جحاو أكلها

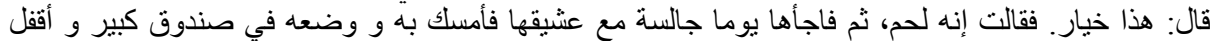

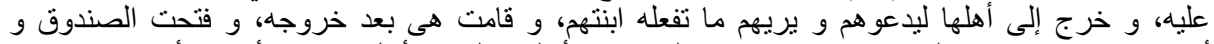

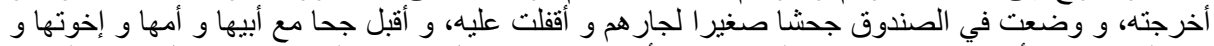

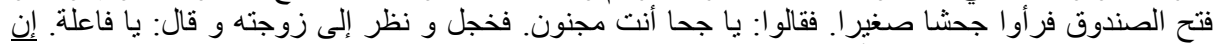
التي تجعل اللحم خيار ا، تسنطيع أن تجعل ابن آدم حمار !! (ج. 14: 147).

Aquí, la palabra (حمارا) puede ser interpretada en sentido literal, si se refiere al amante que fue sustituido por el burro, o en sentido figurativo, si alude al marido ultrajado. El contexto no nos permite inclinar la balanza por ninguna de las dos interpretaciones, puesto que el emisor ha bloqueado intencionadamente las pistas que nos podían ayudar en este sentido. Justamente en este hecho -apoyado por la paronomasia-, descansa el tono jocoso que posee el enunciado de Ŷuhā.

\section{VAGUEDAD Y HUMORISMO}

Tal como quedó establecido en la primera sección de este trabajo, la vaguedad de las unidades lingüísticas se manifiesta en forma de frontera borrosa entre ciertos términos implicados y otros contiguos, que pertenecen a la misma categoría. Para la correcta interpretación de los enunciados donde aparecen, el receptor necesitará determinar siempre la perspectiva desde la que el emisor considera la realidad externa a la que se aplican los términos vagos. De ahí que automáticamente surja el humor, si no se adopta la perspectiva adecuada para la situación en la que se encuadra el lexema de contenido vago. Veamos el siguiente texto:

كان الحديث يدور في مجلس تيمورلنك عن عذاب يوم القيامة و ما بلقى فيه الكفار من شقاء و أهو ال، و كان

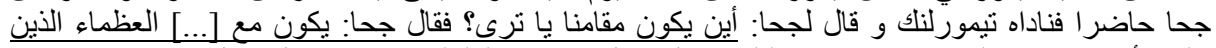

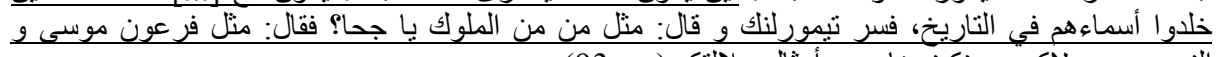

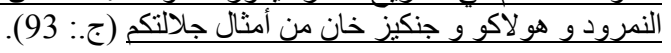

Lo gracioso aquí emana del hecho de que Ŷuhāa utiliza un lexema de contenido vago como (العظماء), para referirse a ciertos reyes mundialmente conocidos, adoptando para ello una perspectiva meramente histórica. Ésta choca diametralmente con la del rey déspota que le formula la pregunta, puesto que el soberano está hablando de la recompensa que en la otra vida recibirán los fieles por sus buenas obras. La perspectiva del monarca tiene, pues, un carácter exclusivamente religioso. Por tanto, en un primer momento se cree que Ŷuhāa está elogiando al dictador, pero cuando éste le pide más aclaración, nos damos cuenta de que la posición adoptada por el cortesano para aplicar el adjetivo (عظيم) ya no es la bondad religiosa, sino el despotismo. De esta forma, el adjetivo pasa a transmitir un valor negativo en vez del contenido positivo que se le aplicaba en un primer momento. El choque entre las dos perspectivas aplicadas es lo que origina la comicidad en este texto. 
En otras ocasiones, la hilaridad deriva de una complementación -o de cualquier otro procedimiento lingǘstico- que contribuye a desdibujar la perspectiva adoptada, de modo que resulta dificil apreciar el valor exacto que el emisor confiere al lexema utilizado:

$$
\text { إن عر ائس اليوم غالية الثمن كالطماطع و اللحوم! (س.: 952). }
$$

Lo único que hace el segmento que aparece a continuación del adjetivo implicado es confundir al oyente, puesto que los objetos mencionados posteriormente cuestan muy poco y no pueden ser calificados de (caros), si se comparan con los gastos del matrimonio. No queda claro, pues, si el emisor utiliza este adjetivo para calificar individualmente a los objetos de los que se habla, en comparación con su precio en el pasado, o si la comparación se realiza, en cambio, entre (las novias de hoy), por un lado, y (los tomates) y (la carne), por el otro. En el segundo supuesto, el enunciado adquirirá un tono evidentemente irónico y el choque entre las dos perspectivas adoptadas dará pie a la creación del humorismo, tal como sucede en el caso de la anécdota de Ŷuhāà.

\section{CONCLUSIONES}

Hemos distinguido en este estudio tres categorías diferentes de opacidad semántica: la ambigüedad, la vaguedad y la indeterminación. Se trata de tres fenómenos que se producen en distintas áreas del plano semiótico del lenguaje. El receptor, por su parte, los ha de resolver en diferentes momentos del proceso de interpretación. Así, si enfocamos la problemática desde la perspectiva de la teoría de la Relevancia, observaremos que la homonimia relacionada con la ambigüedad suele quedar resuelta en la primera subtarea de desambiguación, mientras que las dificultades planteadas por los segmentos vagos o indeterminados se despejarán, básicamente, en la fase correspondiente al enriquecimiento.

\subsection{AMBIGÜEDAD Y HUMORISMO:}

Teniendo en cuenta los mecanismos de desambiguación, es fácil observar que en el discurso humorístico el emisor intenta bloquear o inutilizar el conjunto de resortes en los que puede apoyarse el receptor para llevar a cabo la adecuada interpretación del mensaje. Para que la comicidad se origine, el bloqueo de los supuestos contextuales y/o situacionales ha de ir acompañado de la violación de cierta regla. En nuestro corpus hemos observado tres tipos de infracciones:

a) El uso de una expresión insolente o comprometedora: en tal caso, el emisor se escuda en la responsabilidad que asume el receptor, para hacerle partícipe de las consecuencias interpretativas de las dilogías implicadas.

b) La violación de la congruencia del texto: lo que se observa aquí es la existencia de una especie de choque entre dos congruencias, que confluyen en una misma palabra o expresión ambivalente. 
c) La violación del principio de convencionalidad semántica: una vez que una estructura se haya establecido como expresión fija, el hablante ya no dispone de la libertad habitual para utilizar ninguno de sus componentes en el sentido que pueden transmitir individualmente en la lengua. Recuperar el significado original en tales casos creará siempre hilaridad en el texto.

En todos estos supuestos, se observa la existencia de una superposición intencionada de acepciones. La suerte del enunciado humorístico dependerá entonces de si el receptor se percata o no de la multiplicidad de sentidos que se le presentan. No obstante, en otras ocasiones ocurre justamente lo contrario, esto es, el receptor percibe la existencia de más significados que aquellos que el hablante pretende transmitir. Dos condiciones han de cumplirse para que la comicidad se produzca en este segundo caso:

a) Que el oyente se dé cuenta de la superposición de significados.

b) Que uno de los posibles sentidos sea comprometedor para el hablante.

\subsection{INDETERMINACIÓN Y HUMORISMO:}

La indeterminación de los elementos imprecisos ha de ser completada y ajustada, por parte del receptor, a los requisitos de relevancia óptima mediante enriquecimiento. A tal fin, se ha de disponer de los datos necesarios para contestar a tres preguntas básicas, cuyas respuestas son esenciales de cara a la adecuada interpretación de los enunciados:

a) ¿De qué se habla?

b) ¿Con qué intención?

c) ¿Cómo se configura el mensaje?

En los enunciados humorísticos basados en la indeterminación semántica, se percibe siempre cierta infracción que se comete con el objetivo de bloquear la respuesta a cualquiera de las tres preguntas que acabamos de mencionar. Cada una de dichas preguntas se relaciona con una categoría distinta de indeterminación:

a) Indeterminación referencial.

b) Indeterminación ilocutiva.

c) Indeterminación codificadora.

\subsection{VAGUEDAD Y HUMORISMO}

Para la correcta interpretación de los enunciados donde aparece un término vago, el receptor ha de determinar siempre la perspectiva desde la que el emisor considera la realidad externa a la que se aplica el término. De ahí que automáticamente surja el humor cada vez que no se adopte la perspectiva adecuada para la situación en la que se encuadra el lexema implicado. 